\title{
TELEVISÃO E ESCOLA: ESCOLAS PARALELAS? ${ }^{1}$
}

\section{A televisão não é um bicho-papão, cabendo principalmente à escola dar condições para que as crianças e os jovens desvelem os truques e as fantasias do ritual televisivo}

Com esta reflexão apresento algumas considerações sobre a televisão e sua inserção no dia-a-dia da grande maioria dos cidadãos brasileiros. Programação que seduz e envolve com suas artimanhas, muitas vezes imperceptíveis. Exponho, ainda, algumas conclusões sobre a aproximação/distanciamento entre a escola e a TV, instâncias institucionalizadas, organizadas da sociedade civil e reconhecidas como instância de lazer (a TV) e instância de saber e conhecimento (a escola), sendo ambas "freqüentadas" por crianças e jovens, independente de sexo, idade ou classe social.

Que fascínio exerce a televisão, a ponto de justificar a intensidade de seu consu-

\section{A AUTORA}

Tânia Maria Esperon Porto

Professora da Fundação Universidade do Rio Grande-RS, mestre em Tecnologia Educacional/INPE-SP e doutoranda da Faculdade de Educação da USP. mo pelas pessoas em geral e pelas crianças e jovens particularmente?

Para Moran, a TV "combina-integra a linguagem visual, oral, sinestésica, musical e escrita. Encontra fórmulas que se adaptam à sensibilidade do homem moderno, usando uma linguagem concreta, plástica, com doses curtas de informação e com ritmo acelerado e contrastado. Complementa-se com cenários, personagens, sons, imagens, ângulos e efeitos especiais. Os temas não são aprofundados, explorando os ângulos emocionais, contraditórios, inesperados, exigindo envolvimento, porém com pouco esforço do receptor. As linguagens da TV são dinâmicas, respondem à sensibilidade dos que a vêem, trabalham com a imaginação, com os sentimentos e com a emoção, na dualidade ficção-realidade"'

No entender de Baudrillard, a TV abole toda a distinção entre ficção e realidade, permitindo apenas uma "percepção-tela, onde a imagem só remete a si própria (...) ela coloca o problema da sua indiferença ao mundo, e portanto o da indiferença virtual com a qual a recebemos..." ${ }^{3}$. Um exemplo

1. Elaborado a partir do texto apresentado no XVII Congresso Brasileiro de Pesquisadores da Comunicação - INTERCOMUNIMEP, Piracicaba, setembro de 1994.

2. Apud PORTO, Tânia Maria Esperon. A televisão e a criança que a vê. A didática em revista. Rio Grande, n.1, v.1:36-45, jul./dez. 1994. p.37-38.

3. BAUDRILLARD, Jean. Televisão/revoluçâo: o caso Romênia. In: PARENTE, André. Imagem máquina. Rio de Janeiro: Ed.34, 1993, p.147. 
bem claro disto é que 25 anos depois da chegada do homem à Lua, ainda há pessoas que atribuem este fato a uma "fantasia armada pela televisão" (conforme dados apresentados no Globo Repórter do dia 15 de julho de 1994, pela TV Globo), porém, certamente, quando assistirem à novela ou mesmo quando estiverem frente a frente com um de seus atores, vão referir-se a ele pelo nome da personagem da sua última participação em telenovela.

De acordo com o autor, a rua "torna-se um prolongamento do estúdio, isto é, prolongamento do não-lugar do acontecimento, do lugar virtual do acontecimento"4.

Através da TV são introduzidos novos modelos, novos conceitos, novas imagens para "subverter ou consolidar o imaginário do receptor"5. Os espectadores são despertados para "novas" emoções, para descobrir fantasmas adormecidos ou mesmo para o consumo publicitário.

A mídia, para funcionar, precisa do público e para garantir que fiquem "ligados na telinha", precisa criar, estimular e/ou se adaptar às necessidades de consumo da classe média; para isso está sempre se alterando. Procura, através de pesquisas de audiência, satisfazer as aspirações e despertar $o$ interesse do telespectador. Cria estratégias que façam com que o supérfluo pareça necessário. Os dados do IBOPE - Instituto Brasileiro de Opinião Pública - indicam a identificação do público com o programa ou fornecem informações para as alterações necessárias.

Apesar de todo este avanço tecnológico, a escola (principalmente a pública) encontrase em outra extremidade, voltada para a produção cultural conservadora. Na sua diversidade de organização, tanto a escola pública quanto a privada, na multiplicidade de condições em que se apresentam, constituem-se, de modo geral, mais em espaço de reprodução do que em espaço de produção cultural.

A escola pública situa-se, no entender de Silva Júnior, "na confluência da sociedade civil e da sociedade política (...) sendo o local da luta ideológica, do entrechoque das idéias e das convicções"6.

Como local de tantos problemas representativos do momento sóciopolitico-econômico da sociedade brasileira, a escola constitui-se num universo de contradições que influenciam o processo de ensino e de aprendizagem, estando aquém da evolução tecnológica do tempo presente $e$ distanciando-se, cada vez mais, das necessidades dos professores, dos alunos e da comunidade.

Para Federighi, o mau desempenho escolar do aluno é "multideterminado, onde um fato parece claro: o aluno não está integrado à escola ou a escola não possibilita integração ao aluno" 7 .

\section{SEDUÇÃO VERSUS APRENDIZADO}

Acredito que o problema do fracasso escolar configurado na retenção e na evasão se encontra não só na não integração do aluno à escola e à série mas, principalmente, nos problemas originados pela estrutura $\mathrm{e}$ organização da própria escola brasileira que continua aquém de nossa realidade.

$\mathrm{O}$ aluno convive com duas situações: ora tendo que seguir os parâmetros propostos e exigidos por uma escola reprodutora $\mathrm{e}$ ora vendo, através da mídia, uma realidade dinâmica e estética da sociedade cuja cultu-

4. BAUDRILLARD, J. op. cit. p.148-149.

5. MARCONDES FILHO, Ciro. Televisão: a vida pelo vídeo. 3.ed. Săo Paulo: Moderna, 1988. p.27.

6. SILVA JR., Celestino Alves da S. A escola pública como local de trabalho. 2.ed. São Paulo: Cortez, 1993. p.15.

7. FEDERIGHI, Maria Dirce. Monitoria na 5: série: uma proposta pedagógica. São Paulo: Universidade de São Paulo, Faculdade de Educação, 1989. p.9. (Dissertação de Mestrado) 


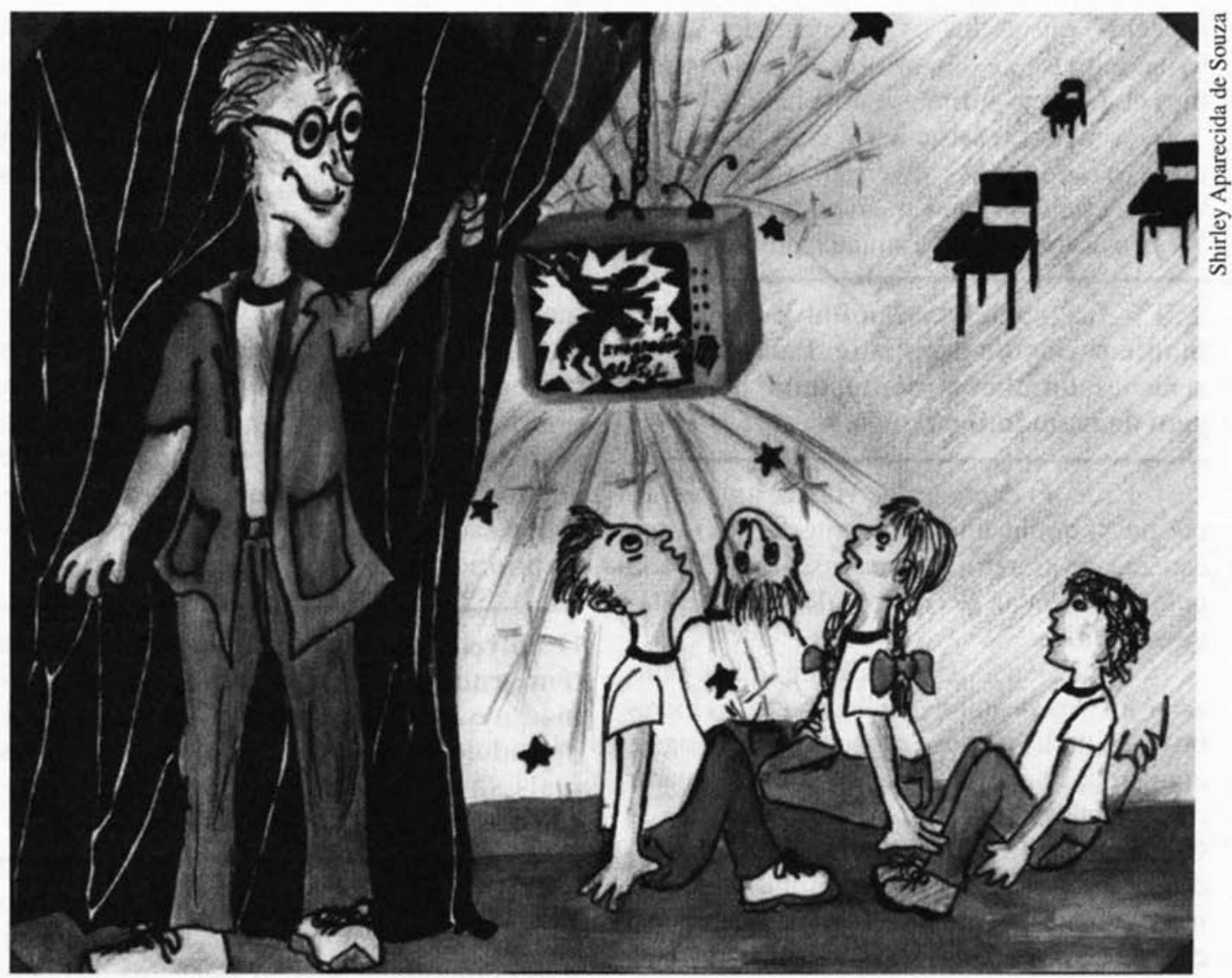

ra está em constante efervescência. Todavia, em ambas, acontece o apelo conservador. Um deles, o da TV, é de livre (aparente) escolha, rege-se pela lógica do mercado, cria e reproduz a ideologia dominante, sendo porém sedutor e socialmente legitimado; o outro, o da escola, é impositivo e de certa forma constrangedor, legitimador do saber, do conhecimento, reproduzindo a ideologia dominante.

De acordo com Penteado, a televisão, "embora não pretendendo ensinar ensina e a escola, com o objetivo de ensinar, ensina pouco ou mesmo não ensina"».

As novas gerações têm novos modos de compreender e de se envolver com as questões atuais. Os estudantes de hoje já nasceram sob a influência dos meios de comunicação de massa e, conseqüentemente, já criaram outros códigos para o entendimento e o envolvimento com os mesmos.

Estes jovens alfabetizaram-se utilizando símbolos "imagéticos" associados à cognição e não apenas símbolos "cognoscitivos" como as gerações anteriores.

Na sociedade moderna, a TV é assistida pela quase totalidade das crianças e dos adolescentes. Quando observo o papel que este meio ocupa na vida dos estudantes constato o seu lugar privilegiado.

Nas pesquisas que realizei com a quarta série de uma escola particular e com a quinta série de uma escola pública (ambas em Campinas-SP), constatei, entre outros 
aspectos, que todos os entrevistados assistem à televisão e dão prioridade aos programas de ficção - filmes e novelas.

A maioria assiste à TV com os pais, irmãos e sozinhos; conversam sobre o que vêem na "telinha", mostrando que $o$ ato de ver TV não acaba quando termina o programa.

A TV faz parte da família e com esta mantém vínculo constante. Participa das relações familiares como uma personagem de igual importância.

Cria, no entender de Havel, uma espécie de "família única, gigantesta, (...) uma espécie de fraternidade monstruosa, ligada pela experiência de noites idênticas e relações idênticas"”.

Dependendo da situação em que é utilizada, a TV pode inibir o diálogo entre os membros da família ou pode proporcionar diálogo e aproximação com a família e amigos a partir dos conteúdos dos programas. No entender de Gomes ${ }^{10}$, a família como "primeira comunidade de apropriação" deve determinar de antemão o tempo e o tipo de programa permitido à criança ver, embora a maioria se omita ou mesmo não perceba essa necessidade.

Na pesquisa citada com a quarta série da escola particular, $70 \%$ dos alunos assistem a até quatro horas diárias. Este índice é semelhante ao dedicado às atividades escolares, com a diferença de que muitos vão à escola por obrigação e a TV é assistida por prazer e interesses próprios.

Os dados da escola pública (alunos de quinta série) mostram que o índice é superior. Os alunos assistem em média de seis a sete horas diárias.

Pelas escolhas dos estudantes das duas escolas, observei que, nesta faixa etária, "além de darem preferência à Globo, vêem mais programas para adultos que programas infantis, entrando em contato, por meio das representações, com o mundo e a cultura dos adultos mais cedo do que as gerações anteriores"11.

Os alunos pesquisados, independentemente de sexo, estão numa faixa etária na qual a imagem, o lazer, o lúdico e o humor têm prioridade, extrapolando o nível dos conteúdos culturais que são considerados prioritários pela família, pela escola e pela sociedade. Mesmo entre os programas de adultos, escolhem os que enfatizam a ficção, a sátira, o humor, a ação e o jogo, dando prioridade às novelas deste gênero.

O entretenimento e as histórias fictícias têm grande influência sobre o comportamento e as atitudes sociais das crianças e dos adolescentes, que introjetam modelos mais significativos segundo sua percepção e os utilizam em situações reais.

Nas duas escolas, a maioria dos alunos não percebe a TV como capaz de influenciar seus comportamentos. Witter ${ }^{12}$, na sua pesquisa com adolescentes, obteve o mesmo dado, justificando-o pelas especificidades próprias da idade.

\section{FANTASIA E REALIDADE}

Os estudantes têm bem presentes a fantasia e a ficção existentes na telinha, diferente, na maioria das vezes, do seu cotidiano, porém entregam-se a elas com naturalidade.

Algumas experiências nos EUA, principalmente de pais preocupados com a alta exposição da criança a este veículo, têm si-

9. HAVEL, Vaclav. A grande familia da televisão. Apud: KUSSI, Peter. LIEHM, Antoni. COHL, Karz. Writing on the wall. New York: Publishing Inc., 1983.

10. GOMES, Guilherme Orozco. Recepción televisiva: tres aproximaciones y una razón para su estudio. México, DF: Universidad Ibero-Americana: Programa Institucional de Investigación, Comunicación y Prácticas Sociales, 1991.

11. PORTO,Tânia M.E. op.cit. p.40.

12. WITTER, Carla. A televisão e o adolescente: análise de conteúdo da programação preferida. São Paulo: Universidade de São Paulo, Instituto de Psicologia, 1991. (Dissertação de Mestrado) 
do empreendidas no sentido de "eliminá-lo" da vida de seus filhos. Graham ${ }^{13}$ conta alguns casos de crianças e de adolescentes que mudaram suas atitudes radicalmente depois que deixaram de assistir a TV.

Em contrapartida, ainda no mesmo artigo, John C. Wright coloca que "este meio de comunicação chegou pra ficar... As crianças vão processar informações cada vez mais das telas e menos dos papéis. Pensar que se está fazendo um favor ao seu filho ao levá-lo a valorizar as coisas antigas em detrimento das coisas de que realmente precisará é criá-lo de forma incompleta"14.

A TV é uma realidade e não há como evitá-la. Conhecê-la melhor e conscientizar-se dos significados que veicula é a maneira mais segura de evitar os males que podem advir de um uso indiscriminado. É a melhor atitude.

Os olhos mágicos da câmera televisiva estão transformando os conhecimentos e a percepção do mundo. A maioria da população só tem oportunidade de ver, ouvir e ler o mundo pelos olhos da TV e, para esta geração sob o "império televisivo", o espetáculo retratado atende todas as expectativas e necessidades.

As pesquisas mostram que os alunos não são seres passivos. Assistem à TV apreendendo as mensagens que mais se adaptam ao seu modo de ser e de ver as coisas, utilizando-se das representações sociais para compor sua leitura: tornam-se "operadores das mensagens".

Para Rosado ${ }^{15}$, representação social significa que, diante de cada objeto social (concre- to ou abstrato), o indivíduo constrói uma certa idéia que lhe permite interagir com esse objeto segundo os modelos de conhecimentos introjetados.

$\mathrm{O}$ aprendiz passa da percepção da imagem para a transformação da informação e sua respectiva codificação em características, estruturas e relações. Ainda segundo a autora, a imagem funciona como uma "dobradiça" que articula o interior do sujeito, seu imaginário, suas idéias, suas motivações e seus conhecimentos aos elementos do mundo real.

A aprendizagem acontece quando o aprendiz tem uma motivação particular para aprender, a qual lhe permite interpretar a realidade a partir do quadro de referências já adquirido.

Referindo-se à literatura, Benjamim afirma que o leitor busca na obra de ficção o que não encontra na realidade: um sentido explícito e reconhecido. Por isso ele se envolve e espera encontrar o "final feliz", o sucesso, o fracasso ou mesmo a "morte do herói", "para poder concluir, por fim a história" '16. É preciso resolver a questão do significado da existência, para provar que o "herói" não viveu em vão e, portanto, reflexivamente, ele leitor, tampouco.

\section{IDENTIFICAÇÃO E SENSO CRITTICO}

Com a televisão acontece algo semelhante. $\mathrm{O}$ aluno pesquisado também se identifica com a personagem, procurando a conclusão do conflito que ele não consegue resolver.

13. GRAHAM, Ellen. $O$ isolamento de quem não vê TV. Gazeta Mercantil. 4 de março de 1994. p.8. (reproduzido pelo The Wall Stret Journal)

14. WRIGHT, J.C. op. cit. p.8, grifos da autora.

15. ROSADO, Eliana Martins da Silva. Communication mediatisée et processus d'évolution des representations. Étude de cas: la representation de l'informatique. Université Lumière Lyon, Institut de Psychologie, 1990. (Tese de Doutorado em Psicologia)

16. BENJAMIN, Walter. Magia e técnica, arte e política. Ensaios sobre literatura e história da cultura. 4.ed. São Paulo: Brasiliense, 1985, v.1.p.15.(Obras escolhidas) 
Na sociedade brasileira, devido às atuais contingências sócioculturais-econômicas, o indivíduo vê-se cada vez mais impossibilitado de realizar seus desejos e necessidades pessoais e profissionais; logo, nas histórias que vivencia, procura o final feliz.

A magia que as histórias representam dá-lhe segurança pois vêm ao encontro de suas fantasias e criações, enquanto criança ou enquanto adolescente.

A televisão, através de suas histórias, proporciona a catarse, fazendo com que o jovem telespectador se envolva e deixe brotar seus sentimentos, seus desejos, suas emoções e suas soluções.

A TV não altera radicalmente quadros já existentes. Para Marcondes Filho, "ela capta aquilo que falta às pessoas, dando-lhes uma satisfação superficial e aparente" 17 .

"A TV apresenta muitas necessidades nunca satisfeitas e nem realmente necessárias. Pode até dar, para alguns telespectadores menos avisados, esperanças utópicas, favorecendo, inclusive, a frustração e, possivelmente, a agressividade" 18 .

A TV, como "absorvedora" da maioria das horas livres dos sujeitos, contribui para formação de seus conceitos, valores, pa- drões de comportamentos e desperta interesses e necessidades nos mesmos, não proporcionando, porém, meios para $o$ atendimento de tais necessidades.

A TV máquina apresenta o mundo encantado onde tudo é permitido e tudo é possível. Trabalha com o simulacro, a reprodução de duas dimensões sobrepostas da realidade: o real (mundo dito normal) e a fantasia (sobrenatural).

Independentemente da classe social a que pertença o jovem telespectador, é importante o acompanhamento e a orientação dos pais e da escola para a leitura e consumo da televisão. É preciso ensinar a desvelar a TV, estudando alguns de seus rituais na linguagem e no conteúdo.

A escola tem que se voltar para a leitura deste traço cultural se quiser acompanhar a velocidade das transformações que as novas gerações estão vivendo.

Para tanto a escola pode aproveitar a participação do aprendiz na reconstrução crítica da imagem/mensagem, sem perder de vista a carga estética, artística e a importância do envolvimento emocional proporcionados pelo espetáculo televisivo. Tem, para isso, que se fazer real e dinâmica e ouvir as necessidades dos sujeitos da educação. 